\title{
Extreme Hyperkalemia in a Hemodialysis Patient Presenting with Cardiac Arrhythmia
}

\author{
(D) Ayşe Serra ARTAN, iD Meltem GÜRSU, io Ömer Celal ELÇiOĞLU, id Yelda DELIGG̈ZZ BiLDACI, id Rümeyza KAZANCIOĞLU
}

Bezmialem Vakif University Faculty of Medicine, Department of Nephrology, İstanbul, Turkey

\begin{abstract}
Hyperkalemia is commonly seen in hemodialysis patients and is a potentially life-threatening condition. Serum potassium concentration greater than $10 \mathrm{mEq} / \mathrm{L}$ is defined as extreme hyperkalemia. Emergent treatment of hyperkalemia is made with intravenous calcium, insulin-dextrose solutions, diuretics, gastrointestinal cation-exchange resin and dialysis. We present here a 52-year-old chronic hemodialysis patient with extreme hyperkalemia and cardiac arrhythmia. She was treated with emergent hemodialysis. Her abnormal laboratory findings and electrocardiography recovered. Further examinations suggested insufficient hemodialysis treatment as the possible cause of hyperkalemia.
\end{abstract}

Keywords: Arrhythmia, extreme hyperkalemia, hemodialysis

\section{Introduction}

Hyperkalemia may cause paresis, life threatening cardiac rhythm disturbances and requires urgent management. Hyperkalemia is defined as a serum potassium concentration higher than 5.5 $\mathrm{mEq} / \mathrm{L}$. Severe hyperkalemia is defined as a serum potassium concentration exceeding $7 \mathrm{mEq} / \mathrm{L}$. Extreme hyperkalemia ( $>10$ $\mathrm{mEq} / \mathrm{L})$ is a very rare condition. It has a high death risk. Only a few patients are reported to survive it (1).

\section{Case Report}

A 52-year-old female patient was admitted to the emergency department with weakness. She was an anuric chronic hemodialysis patient. Her vascular access was provided by a left brachiocephalic fistula. Physical examination revealed generalized muscle weakness, collateral veins on her chest, scars of previous arteriovenous fistula operations on her left forearm and a blood pressure of $175 / 95 \mathrm{mmHg}$. In laboratory examinations, serum creatinine was $10.9 \mathrm{mg} / \mathrm{dL}$ (the normal range is 0.5 to $1.1 \mathrm{mg} / \mathrm{dL}$ ) and urea was $287 \mathrm{mg} / \mathrm{dL}$ (the normal range is 21 to $43 \mathrm{mg} / \mathrm{dL}$ ). Serum potassium concentration was reported to be higher than $10 \mathrm{mEq} / \mathrm{L}$ (the normal range is 3.5 to $5.1 \mathrm{mEq} / \mathrm{L})$. A blood sample for the measurement of serum aspartat aminotransferase (AST) level to exclude hemolysis was taken at the same time and AST was found $12 \mathrm{U} / \mathrm{L}$ (the normal range is 5 to $34 \mathrm{U} / \mathrm{L}$ ). Electrocardiography (ECG) showed widened QRS waves and disappearance of $\mathrm{P}$ waves (Figure 1A). Emergent medical treatment with intravenous calcium, insulindextrose solution and gastrointestinal cation-exchange resin was given and an emergent hemodialysis was performed. Blood test results after the hemodialysis session were as follows: Creatinine: $6.4 \mathrm{mg} / \mathrm{dL}$, urea: $161 \mathrm{mg} / \mathrm{dL}$, serum potassium: $7.5 \mathrm{mEq} / \mathrm{L}$. After the second session of hemodialysis, laboratory results showed a serum creatinine of $4.65 \mathrm{mg} / \mathrm{dL}$, urea of $79 \mathrm{mg} / \mathrm{dL}$, and a serum potassium concentration of $5.2 \mathrm{mEq} / \mathrm{L}$. The complaints of the patient and pathologic ECG findings disappeared completely and

Address for Correspondence: Ayşe Serra ARTAN, Bezmialem Vakif University Faculty of Medicine, Department of Nephrology, İstanbul, Turkey E-mail: ayseserra@gmail.com ORCID ID: orcid.org/0000-0002-6461-3178

Cite this article as: Artan AS, Gürsu M, Elçioğlu ÖC, Deligöz Bildacı Y, Kazancıoğlu R. Extreme Hyperkalemia in a Hemodialysis Patient Presenting with Cardiac Arrhythmia. Bezmialem Science 2019;7(4):345-7. 
normal sinus rhythm was restored (Figure 1B). The patient was discharged after three days of hospital stay and three sessions of hemodialysis treatment.

The patient's consent to publication was obtained.

\section{Discussion}

Hyperkalemia is frequently seen in patients with end stage renal disease. A total of $26.4 \%, 13.8 \%$, and $4.9 \%$ of hemodialysis patients were found to be hyperkalemic with pre-dialysis serum potassium levels of more than $5.1 \mathrm{mEq} / \mathrm{L}, 5.5 \mathrm{mEq} / \mathrm{L}$ and 6 $\mathrm{mEq} / \mathrm{L}$, respectively (2). Hyperkalemia in hemodialysis patients is associated with mortality, hospitalization and emergency department admissions (3).

Most of the hemodialysis patients are anuric or have a very small volume of residual urine. In this group of patients, colonic potassium excretion increases. By help of the cellular adaptation mechanisms, hyperkalemia is better tolerated with less cardiac complications and pathologic electrocardiographic changes compared to the healthy population (4). However, a serum potassium level of $>6 \mathrm{mEq} / \mathrm{L}$ requires prompt treatment. The major causes of hyperkalemia are increased dietary intake, inadequate potassium removal during hemodialysis, excessive potassium release from the cells into the extracellular space and pseudohyperkalemia. Increased dietary intake is mostly related to dietary incompliance. Dialytic removal of serum potassium depends on the frequency and duration of the hemodialysis session, surface area of the dialysis membrane, blood and dialysis solution flow rates, potassium concentration of the dialysis solution and the adequacy of the vascular access (5).

Our patient was evaluated for the possible causes of hyperkalemia. She was compliant with the diet and she was not skipping or shortening her hemodialysis sessions. Rhabdomyolysis or hemolysis were excluded with blood tests. She did not use medications which may have increased serum potassium levels

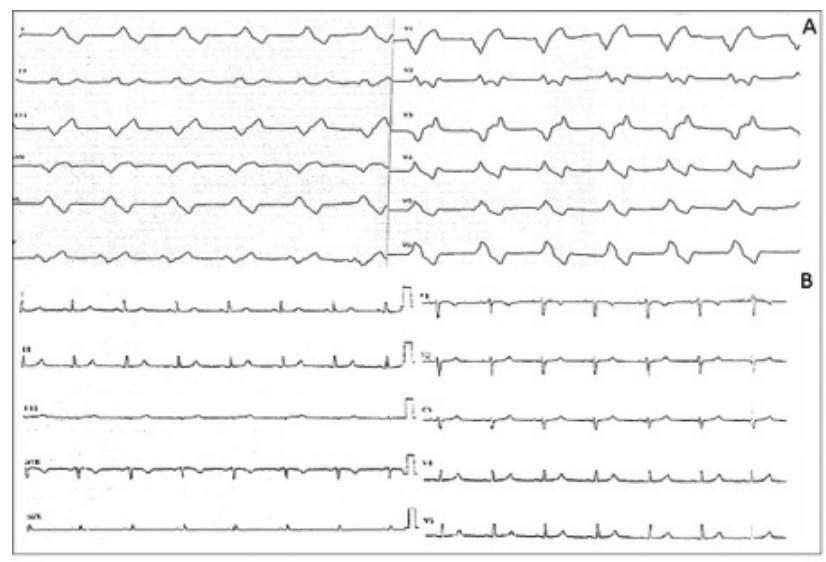

Figure 1. ECG recordings of the patient pre- $(A)$ and postdialysis (B) with a potassium concentration of $>10$ $\mathrm{mEq} / \mathrm{L}$ and $5.2 \mathrm{mEq} / \mathrm{L}$ respectively

ECG: Electrocordiography like spironolactone, angiotensin-converting enzyme inhibitors, angiotensin receptor blockers or beta blockers. Extensive collateral veins on her chest, scars of previous unsuccessful arteriovenous fistula operations on her arm and the finding that the arterial and venous cannulation sites on the arteriovenous fistula were only $2 \mathrm{~cm}$ apart, suggested that hemodialysis insufficiency was the presumptive reason for the extreme hyperkalemia. Insufficient hemodialysis was further verified by a kt/v value of 1 and an urea reduction ratio of $55 \%$ in her last hemodialysis visit.

Emergent treatments of hyperkalemia are intravenous calcium to antagonize the membrane actions of hyperkalemia, intravenous insulin-dextrose solutions to drive extracellular potassium into cells, loop diuretics, gastrointestinal cation-exchangeresins and dialysis to rapidly remove excess potassium from the body (5).

The most effective treatment of hyperkalemia in hemodialysis patients is hemodialysis itself. Potassium binders and insulindextrose solutions provide a transient but possibly life-saving treatment when hemodialysis treatment cannot be done immediately. Our patient's complaints, physical, and laboratory findings recovered after three efficient hemodialysis sessions. Her ECG recovered completely.

Extreme hyperkalemia is fatal unless treated without delay. To the best of our knowledge, our patient had one of the highest serum potassium levels reported until now (1). Serum potassium concentration in her first drawn blood sample was found to be higher than $10 \mathrm{mEq} / \mathrm{L}$. A precise value of serum potassium could not be obtained because the laboratory kits in our hospital are not suited for readings of serum potassium concentrations above $10 \mathrm{mEq} / \mathrm{L}$.

Hyperkalemia is a common finding in hemodialysis patients. The most effective treatment for hyperkalemia is hemodialysis. After the emergency treatment, a careful investigation aimed to enlighten the cause of hyperkalemia should be made. Dialysis adequacy, patient's treatment compliance and vascular access should be evaluated at first.

\section{Ethics}

Informed Consent: A consent form was completed by all participants.

Peer-review: Externally peer-reviewed.

\section{Authorship Contributions}

Concept: R.K., Design: A.S.A., Data Collection or Processing: A.S.A., Y.D.B., Analysis or Interpretation: M.G., Ö.C.E., Literature Search: A.S.A., Writing: A.S.A., M.G

Conflict of Interest: No conflict of interest was declared by the authors.

Financial Disclosure: The authors declared that this study received no financial support. 


\section{References}

1. Muck PM, Letterer S, Lindner U, Lehnert $H$, Haas CS. Beating the odd surviving extreme hyperkalemia. Am J Emerg Med 2012;30:250.

2. Rossignol P, Lamiral Z, Frimat L, Girerd N, Duarte K, Ferreira $\mathrm{J}$, et al. Hyperkalaemia prevalence, recurrence and management in chronic haemodialysis: a prospective multicentre French regional registry 2-year survey. Nephrol Dial Transplant 2017;32:2112-8.
3. Brunelli SM, Du Mond C, Oestreicher N, Rakov V, Spiegel DM. Serum Potassium and Short-term Clinical Outcomes Among Hemodialysis Patients: Impact of the Long Interdialytic Interval. Am J Kidney Dis 2017;70:21-9.

4. Einhorn LM, Zhan M, Hsu VD, Walker LD, Moen MF, Seliger SL, et al. The frequency of hyperkalemia and its significance in chronic kidney disease. Arch Intern Med 2009;169:1156-62.

5. Pani A, Floris $\mathrm{M}$, Rosner $\mathrm{MH}$, Ronco C. Hyperkalemia in hemodialysis patients. Semin Dial 2014;27:571-6. 